\title{
POSSIBILITIES OF ATTENTION IMPROVEMENT FOR ADOLESCENTS
}

\author{
Irena Trubina \\ Riga Teacher Training and Education Management Academy (RTTEMA) \\ Latvia
}

\begin{abstract}
Attention is the ability to focus selectively on a selected stimulus, sustaining that focus and shifting it at will. Attention is important to learning and other cognitive processes. Learning is most efficient when a person is paying attention. Adolescence is a critical transition period, during which fundamental changes prepare the adolescent for becoming an adult. The neurobiology of adolescent behaviour have emerged, promoting the central role of reward and motivation, coupled with cognitive immaturities. It was concluded that maturation and experience are significant in the allocation of attention problems and errors during everyday tasks. The aim was to explore adolescents' attention and to compare two methods of focus for improvement. 24 teenagers take a part in this experiment (16 girls, 8 boys). The teenagers were 12-16 (average age 14, 3). Three groups were created (two groups with different methods and control group). The activities lasted 3 months. The first group of respondents (EGA) practiced the author's developed methods of playing music in vocal ensemble twice a week, while the other group of respondents (EGB) practiced with computerized equipment CogniPlus. Attention indicators were analysed using the Vienna Test System (SCHUHFRIED) - COG and WAFF tests. Both tests measured various aspects of attention. It was concluded that the EGA group response time statistically significantly improved compared to baseline $-2.28 \mathrm{sec}$. vs. $1.92 \mathrm{sec}$. $(P=0.039)$, but the EGB and CG groups showed no statistically significant differences. In turn, WAFF test, which has to assess to auditory attention reaction time, EGA group has found no statistically significant differences - $0.74 \mathrm{sec} . v \mathrm{~s} .0 .46 \mathrm{sec} .(P=0.002)$, while EGB are seen only a tendency to improvement in the reaction rate. The results show that although both methods contribute to improvements in attention, however, playing music, influenced by attention statistically significantly. It is planned to continue the study by increasing the number of respondents, as well as the test of attention scores.
\end{abstract}

Keywords: attention, adolescents, the Vienna Test System.

\section{Introduction}

Attention is important in people life, in fact the period of adolescents the identity of personality is strengthen and the new ideas of selfeducation is found out, the attention of adolescents becomes unstable and dispersed.

Modern adolescent independently looking for the new, the unusual, exacerbated by his self-knowledge need, adolescent wants to choose from a wide 
offer that which satisfies his need to be himself, to operate across borders, in order to strengthen its identity (Svence, 1999).

Adolescence is a critical transition period, when fundamental changes are prepared the adolescent for becoming an adult. The neurobiology of adolescent behavior has emerged, promoting the central role of reward and motivation, it is coupled with cognitive immaturities (Ernst et al, 2011).

Conclusion - that maturation and experience are significant in the allocation of attention problems and errors during everyday tasks (Romer et al., 2014). So in crowded information environment necessary to push the teen's attention to alternative methods of self-improvement.

Attention, as a special psychophysiological state, provides a smooth and accurate operation of consciousness. It provides mental activity direction and focusing on a particular object or phenomenon (Kondrova, 2010). Thus, adolescents are able to improve their cognitive processes, which are the main source through which people become aware of the world around them, and the whole process is based on the attention (Vorobjovs, 2000).

Attention is important for learning and other cognitive processes. Learning is most efficient when a person is paying attention. Given that adolescent attention concentration is 15 to 20 minutes, then it is necessary to improve the training, which should be no longer than 40 to 45 minutes a day (Visocka, 2002).

That is a reason why the aim of the study is to compare two methods of improving attention and research the attention of adolescents.

\section{Study materials and methods}

24 adolescents took part in this experiment (16 girls, 8 boys). The adolescents were 12 to 16 years old (average age 14,3). Each group consists of 8 respondents. The number of participants in groups was determined taking into account the focus of one of the properties - the amount that the optimal size of 7 \pm 2 objects covered by the human consciousness a short $(0.1$ to $0.01 \mathrm{sec}$.) amount of time (Miller, 1956).

The study used two methods focus performance-enhancing - the author created the vocal ensemble lessons (experimental group A - EGA) and computerized equipment CogniPlus (experimental group B - EGB), which between them have been compared and tested the control group - CG. The length of research was 3 months two times a week for active groups.

Before and after methods the computerized The Vienna test systems (VTS) were used. This equipment was certificated in Europe (Wagner \& Karner, 2006). The study tests used are high validity indicators that are approved specifically for studies test development company Schuhfried in Vienna. Testing was used to working panel (Figure 1). 


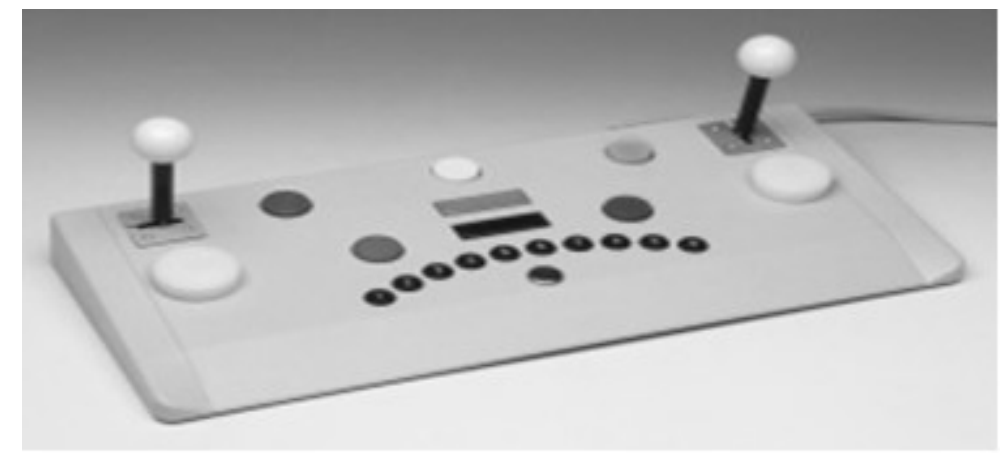

Figure 1 VTS universal test panel

According to the research purpose of VTS was selected tests - Cognitrone test (hereinafter - Cog), S11 test form (60 tasks with no time limit) can be concentrated levels of determination and WAF test to focus sub test auditory attention levels determination (hereinafter - WAFF).

Both tests measured various aspects of attention. The main idea is time of the reaction.

Vocal ensemble lessons (EGA) were chosen as a method in the interests of education is voluntary and its start-up does not require a certain level of education appropriate education (Latvian Education Law, 1999). Music pedagogy studies is emphasized, that music is not just adolescent musical intelligence development, but also the overall development so that they can participate in the cultural life (Zarinš, 2003).

In addition, promoting musical intelligence development, pedagogical studies highlighted that performing - singing, reading music, playing various musical instruments, adolescents are not only integrated into the community's cultural life and heritage identification, but they also develop the ability to better read and numeracy (Fišers, 2005). More specifically, playing the piano is promoted special musical abilities development - hearing, musical imagination, sense of rhythm, musical memory, as well as the overall capacity - abstract thinking, volume - spatial perception, originality, flexibility; focus, shifting, breaking up; memory training; movement psychophysiological abilities - agility, endurance, movement coordination, reaction time, etc. (Marnauza, Gžibovskis, \& Kikȩere, 2009, Voita et al., 2012). So vocal ensemble lessons or collective musicianship gives adolescents universal opportunities for self -improvement.

As already mentioned, the focus is the basic foundation of any advocacy work, so classes - singing process was summarized in a variety of exercises to improve attention. Adapting them for singing, it was established in exercise system vocal ensemble lessons (see. Table 1). Every week, two sessions were held and they were diversified because they were used for different exercises, but the lessons were designed structurally similar, but with a variety of exercises. 
Table 1 Methods for Experimental group A - EGA

(Gžibovskis, 2009; Grauzdiña, Bernhofs, 2009; Voita et al., 2012)

\begin{tabular}{|l|l|l|}
\hline \multicolumn{1}{|c|}{$\begin{array}{c}\text { STRUCTURE OF } \\
\text { ACTIVITIES }\end{array}$} & \multicolumn{1}{c|}{$\begin{array}{c}\text { 1st LESSON OF THE } \\
\text { WEEK }\end{array}$} & $\begin{array}{c}\text { 2nd LESSON OF THE } \\
\text { WEEK }\end{array}$ \\
\hline $\begin{array}{l}\text { The beginning of the lesson }- \\
\text { activities for attraction of } \\
\text { attention }\end{array}$ & 1. Selfcontrol of attention & 1. Attraction of attention \\
2. Miss the number & 2. Who is more careful? \\
\hline $\begin{array}{l}\text { Warming of the voice with } \\
\text { tasks for attention }\end{array}$ & 3. Selection of attention & 3. Selection of attention \\
\hline $\begin{array}{l}\text { Singing with tasks for } \\
\text { attention }\end{array}$ & $\begin{array}{l}\text { 4.Rhythmisation on the } \\
\text { table surface } \\
\text { 5. Canons with chairs }\end{array}$ & 4. Fist - indication \\
\hline
\end{tabular}

Adolescents after long school day need to renew the ability of concentration and auditory attention by using games and other activities. Activities were different with different tasks, but they were structural similar. Percussions, chairs, tennis balls and other attributes are used in the lessons.

At the beginning of attracting attention for vocal ensemble classes two different types of tasks were used. For two weekly classes the first task is similar. On behalf of "Selfcontrol of attention" EGA members sitting opposite a teacher in one row so that all of them should be the same distance from teacher. Teacher agree on acoustic language, such as clapping hands, which is used at times when one of the members of the EGA doesn't hear a word or sentence what teacher said.

During the exercise teacher read fables or instructive story, but the vocal ensemble members listening carefully. Teacher slowly read fables through three voice expression levels: average (voice height to which the teacher is usually running a workshop), high (loud talking with high intonation, for example, to read the text are labeled "Bold" article) and the lowest (whispering, for example, read the text is marked "Italic" article or italics).

On fables reading time if any of the EGA members use acoustic communication language teacher, continues without stopping to read fables to end. After reading fables going reflection on the fables of the contents of the words or phrases that were not to hear, thus enhancing the ability to focus attention and auditory development exercises with the test questions.

By contrast, the second weekly classes on behalf of "Attraction of attention" all EGA members sitting also similar, only teacher reading fables voice does not change expression, but an educator in the hands of a sonorous instrument, such as the tambourine. Teacher picked on certain words or phrases 
are rung tool. Fables these words are "underline" article or underlined. After reading fables reflection occurs similarly to the above-mentioned task. Each of the above tasks at the beginning of lessons takes about 3 - 5 minutes.

The next challenge, EGA participants make different types of motion while standing, because singing time it is important to release the body (Pecham, 2000).

In order to achieve effective results, it is necessary to use such pedagogical techniques that facilitate interaction with adolescents at the social level. The study used a short game, which formed relaxing moments and positive atmosphere throughout the entire lesson (Geidžs \& Berliners, 1998). On behalf of "Miss the number" educator or game manager offering vocal ensemble loud count consecutive numbers, standing in a circle. In addition, figures, containing 3 (3, 13,23 , etc.) or a multiple of three $(6,9$, etc.) is not allowed to call, but instead a member of the vocal ensemble clapped his hands. That participant who names the banned numbers, lose. The winner is the one who remains last. This game could be played, eg, up to the number $27^{\text {th }}$.

In the second lesson of the week game or task "Who is more Careful?" the game manager is selected at the beginning of the game. Other vocal ensemble members - the game participants stand in one row, while the leader stands with his back to them. Then the game manager turns around and try to focused in a short time the order players are standing, then he turns back to the players and try to name the sequence in which all stands. All participants become a game manager in turn. These types of games also takes three to five minutes, but after such activities adolescents have a positive attitude, which helps in further training course and improve adolescent attention.

After the first 10 minutes, which were completed by two tasks, starts warming up the voice - task "Selection of attention" during which the EGA members stand or sit in a circle. The study is used often directly circle principle because, in U. Heske (2007) opinion, more focused sessions is when activities are carried out in a circle, because all the existing circle participants have an eye contact and circle create one whole - group. Ensemble is a collective who sings common songs, it is very important that adolescents feel as a whole group.

To warm up the voices, according to teacher directions vocal ensemble members begins "mmmering, zummering or brummering" (eg, zzz or $\mathrm{mmm}$ ) each random sound in height, creating a "cocktail party" effect (Purves et al., 2008). The teacher sings the individual sounds (of 3 - 5 sounds) and the vocal ensemble of actors, focusing and activating auditory attention, which they need to hear, remember and repeat. To avoid confusion, teacher clap hands, when they need to start zummering and when participants start to do it, teacher starts to sing a warmexercise, but after the playback clapped his hands again zummering has to be paused, and adolescents all together repeat the teacher's a warm-exercise. 
This task could be accomplished with the eyes closed in order to further activate the auditory attention, which is so important for ensemble whole sounding. Such activity can take as far as 10 - 15 minutes.

After warm-up, followed by the singing voice with tasks for attention. The study used a variety of acquired Latvian folk songs. Performance "Rhythmisation on the table surface" promotes thinking speed, flexibility, attention concentration and switching capacity, auditory attention, sensomotorical coordination development. The exercise is performed by sitting or standing at a table at a slow pace quarter notes ripple.

The exercises have been acquired gradually. Exercise can be executed without displacement (both hands at the same time fulfill the same lines) and with 3 different offsets (each hand is simultaneously different lines) connecting with singing. Each week, participants learned the vocal ensemble one of these displacements.

The exercise consists of four movements positions:

- $\quad 1^{\text {st }}$ position - both hands knuckles fastened to the table surface;

- $\quad 2^{\text {nd }}$ position - both hands $1^{\text {st }}$ finger (both together) vertical twist over the table edge, the other fingers tightened fist;

- $\quad 3^{\text {rd }}$ position - of both hands $2^{\text {nd }}$ and $3^{\text {rd }}$ fingers (all together) vertical twist on the table edge, the other fingers tightened fist;

- $\quad 4^{\text {th }}$ position - both hands $2^{\text {nd }}$ and $5^{\text {th }}$ fingers (all together) vertical twist on the table edge, the other fingers tightened fist.

Similar task is „Fist - indication", which consists of 4 positions. During the singing four hand positions are used:

- the starting position - both vertical kept elbows bent hands palms toward you;

- $\quad 1^{\text {st }}$ position - left hand closed fist, right hand with the fingertips point to the left hand so that hands are facing;

- $\quad 2^{\text {nd }}$ position - right hand closed into a fist, the left hand with the fingertips point to the right hand so that hands are facing;

- $\quad 3^{\text {rd }}$ position - continues the previous $1^{\text {st }}$ and $2^{\text {nd }}$ position movements.

At the end of vocal ensemble classes task "Canons with chairs" is used in which each member of the vocal ensemble need one chair with a backrest. Chairs placed in a circle. Study participants make 4 steps away from chair backs forming a large circle around the chairs. Basic exercise is a step, the other leg is making the support leg next to the fingertip as pointing. The exercise has 8 positions. Each position of $4 / 4$ or $2 / 4+2 / 4$ long, depending on the executable songs. Presentation is as follows:

- $\quad 1^{\text {st }}$ bar -4 steps to chair;

- $\quad 2^{\text {nd }}$ bar - put the hands on the chair back and stand (whole note); 
- $\quad 3^{\text {rd }}$ bar - with 4 steps, pass the right side of the chair, stand in front of;

- $\quad 4^{\text {th }}$ bar - sit on the chair (whole note);

- $\quad 5^{\text {th }}$ bar - stand up and stand;

- $6^{\text {th }}$ bar - with 4 steps, pass the left side of the chair, behind;

- $7^{\text {th }}$ bar -4 claps on the back of chair;

- $8^{\text {th }}$ bar - go back with 4 steps.

At the end of lesson the task of "Chestnut" was also used in the vocal ensemble, participants stand in a circle, each has a tennis ball in his hand, which is affixed to the left wrist. Teacher sets the pace and the number of a particular meter. To "one" of the study participants with the right hand and take the ball to the "two" are placed in the adjacent left hand. Such balls are moved without interruption. In order to keep singing during a precise exercise heart rate, exercise teacher spends with tambourine tapping each quarter notes. The exercise has a number of possible variations:

- Give balls to the right;

- Give balls to the left;

- Go on right and give balls to the right;

- $\quad$ Go on left and give balls to the left;

- Go on right and give balls to the left;

- Go on left and give balls to the right;

After an active, the games and exercises based focus emerging lessons need to make last minute reflection, knowledge and skills acquired to strengthen (Гальперин \& Кабыльницкая, 2008).

In turn, members of EGB concentration of attention and auditory attention development was promoted individually with the help of computerized equipment CogniPlus - cognitive development method, which is designed for cognitive function, attention function development. It can be used from the age of 7 . CogniPlus system is customizable for each study participant's level of ability.

Study participants individually visited RTTEMA psychophysiological laboratory for three months twice a week (60 minutes a day) in order to facilitate focusing ability and auditory attention development.

Programm is like a computer game, but without dependence on it. The ALERT form (Figure $2 \mathrm{~A}$ ) was used, where respondent is a biker and he has react on different situations on the road, but Focus form (Figure 2 B), where respondent is sailor and he has to react on different sounds. Both tasks have several levels that are automatically recorded after each lesson. 


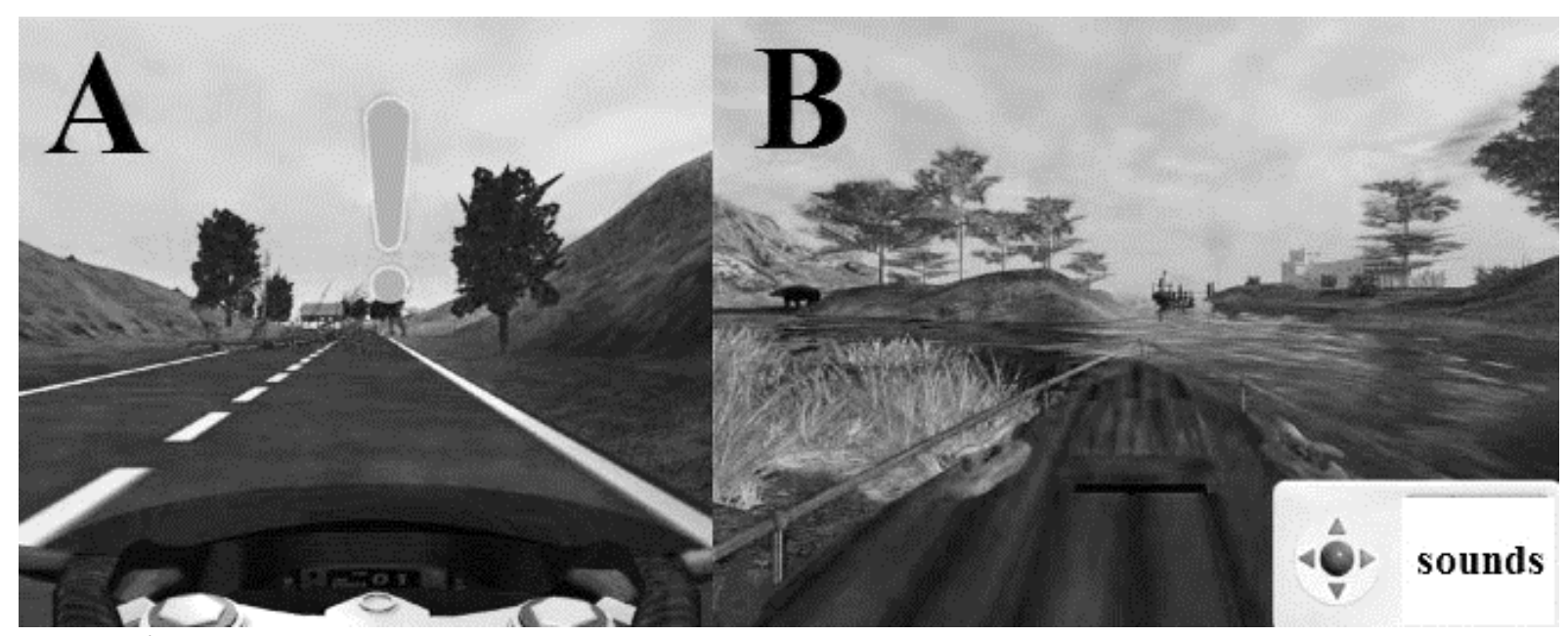

Figure 2 Methods for Experimental group B (EGB) - CogniPlus task samples

After three months, during which the EGA and EGB participants were encouraged to concentrate skills and hearing attention to the development of a variety of methods, all study participants, including CG, took part in the re-testing.

\section{Results}

The study analyzed and compared before and after the two test methods COG and WAFF - key indicators. The two tests they have response times in seconds. Attention concentration was analyzed to determine the dynamics average mean time correct rejection (sec.) of the groups comparison of results in COG test (I) - before methods and in COG test (II) - after methods (Figure 3), which determines the focus of concentration response rate.

It was concluded that the EGA group response time statistically significantly improved compared to baseline $-2.28 \mathrm{sec}$. vs. $1.92 \mathrm{sec} .(\mathrm{P}=0,039)$, but the EGB and $\mathrm{CG}$ groups showed no statistically significant differences.

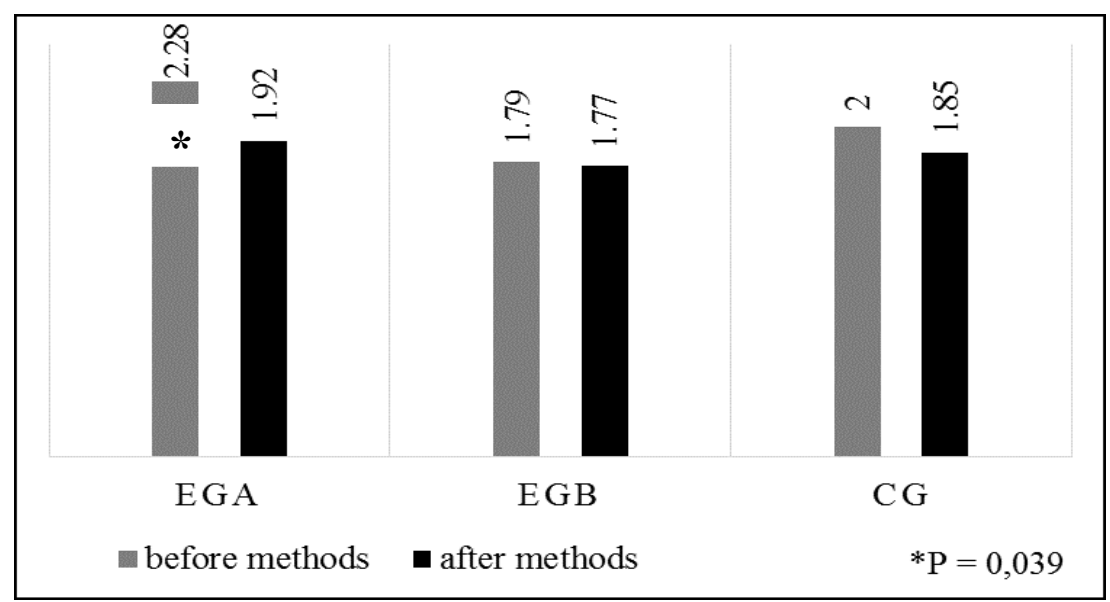

Figure 3 Average mean time «correct rejection» (sec.) of the groups comparison of results in COG test (I) and in COG test (II) 
By contrast, auditory attention dynamics was used to determine the Average reaction time (sec.) Comparison of results in the WAFF test (I) - before Methods and WAFF test (II) - after methods. In turn, WAFF test, which has to assess to auditory attention reaction time, EGA group has found statistically significant differences $-0.74 \mathrm{sec}$. vs. $0.46 \mathrm{sec}$. $(\mathrm{P}=0.002)$, while $\mathrm{EGB}$ and $\mathrm{CG}$ are seen only a tendency to improvement in the reaction rate (Figure 4).

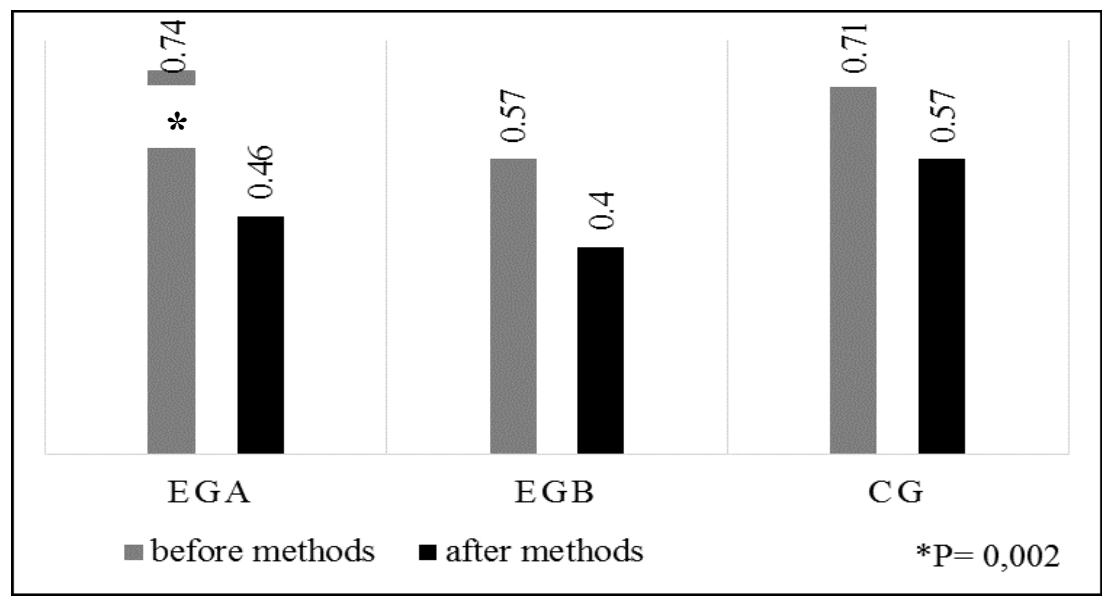

Figure 4 Average reaction time (sec.) comparison of results in WAFF test (I) and WAFF test (II)

It can be concluded that both tests the fundamental variables or key indicators have improved in all groups, but no statistically significant differences were detected.

\section{Conclusion}

Adolescent attention stage of development is very important because it is necessary not only in training but also in other life activities in order to achieve better results. The study tested two methods adolescent attention concentration and attention to the development of hearing - playing music vocal ensemble the author set up a system of exercises and attention training with computerized equipment CogniPlus.

Attention indicators were analysed using the Vienna Test Systems - COG and WAFF tests. Both tests measured various aspects of attention. It was concluded that the EGA group response time statistically significantly improved compared to baseline - $2.28 \mathrm{sec}$. vs. $1.92 \mathrm{sec} .(\mathrm{P}=0.039)$, but the EGB and CG groups showed no statistically significant differences. In turn, WAFF test, which has to assess to auditory attention reaction time, EGA group has found no statistically significant differences $-0.74 \mathrm{sec}$. vs. $0.46 \mathrm{sec} .(\mathrm{P}=0.002)$, while EGB are seen only a tendency to improvement in the reaction rate. The results show that although both methods contribute to improvements in attention, however, 
playing music, influenced by attention statistically significantly. It is planned to continue the study by increasing the number of respondents, as well as the test of attention scores.

\section{References}

Ernst, M., Daniele, T., \& Frantz, K. (2011). New perspectives on adolescent motivated behavior: Attention and conditioning. Developmental Cognitive Neuroscience, 1, 377-389.

Fišers, R. (2005). Mācīsim bērniem mācīties. Rīga: RaKa.

Geidžs, N. L., \& Berliners, D. C. (1998). Pedagogiskāa psihologija. Rīga: Zvaigzne ABC.

Grauzdiña, I., \& Bernhofs, V. (2009). Mūzikas mācība. Müzikas literatūras un solfedžo integrêtais kurss. Koncepcija, materiāli II un III pakāpei. CD. Projekta Nr. 2009/0208/1DP/1.2.1.1.2/09/IPIA/VIAA/005. Tālākizglīīibas kurss: Daudzveidīgas mācību metodes profesionālās ievirzes un profesionālo vidējo mūzikas izglīî̉bas programmu mācību priekšmetā „Mācību valoda”. Rīga: Rīgas Doma kora skolas atbalsta biedrïba.

Gžibovskis, T. (2009). Jauniešu spēju attīstība sitaminstrumentu spēles apguvē. (Promocijas darbs, LU, Rīga, Latvija).

Heske, U. (2007). Darbs komandā: darba grupas vadība. Rīga: Zvaigzne ABC.

Kondrova, A. (2010). Kognitīvo procesu sistēma. Palīgmateriāls skolotājam. Vārdnīca. Uzdevumi. Metodiskais materiāls. LU projekts „Profesionālajā izglìīīā iesaistīto vispārizglītojošo mācību priekšmetu pedagogu kompetences paaugstināšana” (Vienošanās Nr.2009/0274/1DP/1.2.1.1.2/09/IPIA/VIAA/003, LU reg̀.Nr.ESS2009/88). Retrieved from: www.profizgl.lu.lv/mod/resource/view.php?id=21736 (26.01.2017).

Latvijas Republika Saeima. (11.05.2000). LR Izglīitibas likumu (Education Law) 47.pants interešu izglîtības programma. Pieejams: http://www.aic.lv/rec/LV/leg_lv/ LV_lik/izgl_lik.htm\#47 (21.02. 2017).

Marnauza, M., Gžibovskis, T., \& Ķiḳere, V. (01.01.-31.12.2009). Kognitīvo spēju attīstības anatomiskie psihofiziologiskie pamati. Projekts Nr. 09.1128 „Kognitīvo funkciju attīstības metodes izstrāde pusaudžiem ar mācīšanās un kustību traucējumiem".

Miller, G. A. (1956). The Magical Number Seven, Plus or Minus Two. The Psychological Review, 63, 81-97.

Pecham, A. (2000). The Contemporary Singer: Elements of Vocal Technique. Berklee: Press Publications.

Purves, D., Brannon, E. M., Cabeza, R., Huettel, S. A., LaBar, K. S., Platt, M. L., \& Woldorf, M. G. (2008). Principles of Attention. Principles of Cognitive Neuroscience. USA: Sinauer Associates.

Romer, D., Lee, Y. Ch., McDonald, C. C., \& Winston, F. K. (2014). Adolescence, Attention Allocation, and Driving Safety. Journal of Adolescent Health, 54, 6-15.

Svence, G. (1999). Attīstības psiholoğija: Mācību līdzeklis. Rīga: Zvaigzne ABC.

Visocka, I. (2002). Smadzeņu darbības ietekme uz mācību procesu. Skola visiem: palīgs pedagogiem, psihologiem un vecākiem. Redaktores - Miezīte, S., Seile, M.. Rīga: Skolu atbalsta centrs.

Voita, D., Augstkalne, D., Biseniece, Z., u.c. (2012). Integratīva mācību metodika adaptācijai sociālajā vidē kognitīvo un kustību funkciju uzlabošanai. III dal̨a. Projekts Nr. 2009/0305/IDP/1.2.2.2.3.2./09-APIA/VIAA/122 Integratīvas mācību metodikas izstrāde 
un ieviešana adaptācijai sociālajā vidē skolēniem un jauniešiem ar mācīšanās, kognitīvo un kustību traucējumiem. Rīga: RTTEMA.

Vorobjovs, A. (2000). Vispārīgā psihologija. Rīga: Izglītības soḷi.

Wagner, M., \& Karner, T. (2006). Vienna Test System. Manual of Cognitrone. Mödling:Schuhfried.

Zariņš, D. (2003). Mūzikas pedagogijas pamati. Rīga: RaKa.

Гальперин, П. Я., \& Кабыльницкая, С. Л. (2008). Экспериментальное формирование внимания. Москва: Директ-Медиа. 